\title{
EDITORIAL
}

\section{What else can you expect at www.erj.ersjournals.com?}

\author{
P.J. Sterk and K.F. Rabe
}

W hat can you expect from the European Respiratory Journal $(E R J)$ in 2007? As we are all aware, the developments in respiratory science and medicine are more dynamic than ever. Scientific communication has become global and almost instantaneous, and as the Chief Editors we feel that it is our duty to present the ERJ to you as one of the main platforms highlighting the increasing advancements in the field. Effectively, this means that our mission to be "rapid, reliable and responsive" deserves an even more central position in our editorial and publishing strategy.

So, what will be our priorities regarding the content of the Journal? How will this be pursued? And who is going to do it?

\section{THE CONTENT}

The ERJ aims to cover the broadness of respiratory science; it links basic research with clinical studies and vice versa. In this we fully depend on you, as potential authors submitting manuscripts to our Journal. The flavour of the Journal can also be improved by up-to-date review papers. Recently, we have introduced a new section of "perspective" papers, in which new concepts, hypotheses and ideas can be launched. This month, WEST et al. [1] share with us their challenging thoughts about the adequacy of the evolution of the lung. From their "bird's eye" perspective the structure and function of our lungs appears to be rather "down to earth" and far from optimal, even in good health. This kind of analysis is eyeopening and may even help to stimulate real innovations in the treatment of lung disease, as recently introduced by MACKLEM et al. [2].

But the mainstay of the Journal is top-quality original science. Which studies receive the highest priority? This obviously strongly depends on novelty, the relevance of the research question, and on the strength of the design and data. An ideal $E R J$ issue opens with spicy editorials, followed by food for thought from a perspective paper. You can then expect one or two bench-to-bedside articles [3], which aim to bridge the gap between science and clinical care. We also feature strong cell biology and animal studies [4], which provide the scientific foundation of the clinical sciences. We then serve you studies covering the full spectrum of pulmonary medicine. Amongst these, we often give priority to large trials [5], with or without intervention, because these can be definitive in running scientific debates. This leaves more than enough space for relatively small and neat experimental studies, which bring

CORRESPONDENCE: P.J. Sterk and K.F. Rabe, European Respiratory Journal, Chief Editors' Office, Dept Pulmonology, C3-P, Leiden University Medical Center, Albinusdreef 2, P.0. Box 9600, NL2300 RC, Leiden, The Netherlands. Fax: 31 715266927. E-mail: erj@lumc.nl new elements into our thinking on respiratory disease [6]. As many of you know, we love novel technology, so new molecular methods, imaging and proof-of-concept therapy receive relatively high priority in our Journal.

But there is more. Our review papers largely determine the flavour of the month. Here, we strive to present papers with optimal-quality illustrations, with which our Publications Office (Sheffield, UK) can assist. We also expand our review series. Recent series in the ERJ have covered issues such as cell signalling, interventional pulmonology and rare interstitial lung diseases. Last month, we started a series on the genetics of asthma and chronic obstructive pulmonary disease (COPD), and next month a new series on airway remodelling will be launched. Later this year and next year you can expect series on: lung cancer, weaning from mechanical ventilation, management of very severe COPD, animal studies in respiratory medicine, parental smoking and early wheeze, COPD comorbidity, new biologicals in the treatment of respiratory disease, and pulmonary hypertension: from basic concepts to practical management. We have also decided to introduce an annual series related to the Taormina Lung Science Conference. In this way we aim to cover the most dynamic fields, but please do not hesitate to contact us with any other proposals.

\section{THE MEDIUM}

The ERJ reaches out to you through the web, at www.erj.ersjournals.com, and of course in its printed form, which arrives on your doormat every month. We were pleasantly surprised to find that the electronic ERJ has about 1 million hits and 300,000 downloads per month! In order to reduce our publication lag-time (the time between acceptance and publication), we recently introduced electronic pre-publication (Epub) of papers that are in press, which gives readers access to manuscripts right after acceptance via the ERJ in Press button on our site and PubMed. We have also added the option of an online depository. This allows authors to put more detailed methods, supplementary data, figures or comments on the ERJ website. This is optional and can be used at the discretion of the author and/or the editor. Through all this we aim to increase the exposure and citation of your papers. The latter is increasing, given the growth in our impact factor to 3.95 in 2005, the highest ever in the history of the Journal. This makes us the fifth leading journal in the respiratory field, but as we have expressed previously, our ambition regarding this ranking lies somewhat higher. We will continue to make a positive selection of the best papers, which at present means we accept one in five/six submitted manuscripts.

Twice a year, we meet the editors of our colleague journals in the field. This has led to very fruitful discussions and positive 
decisions regarding common policies on, for example, criteria for authorship, conflicts of interest, duplicate publications, scientific fraud, and so on. We strongly believe that this exchange at editorial level will improve the quality and thereby, hopefully, the international position of the respiratory field in general. This is an absolute requirement, and we are very pleased that respiratory diseases are now explicitly mentioned amongst other burning health problems in the very latest EU 7th Framework Programme for research [7].

Based on the above, we will adjust our 2007 instructions to authors at our submission site http://mc.manuscriptcentral. com/erj. This will be based on the uniform requirements for manuscripts submitted to biomedical journals [8] and will include recommendations regarding: ghost authorship [9], duplicate publication [10], statement of interest disclosure [11], registration of clinical trials [12], guidelines for clinical trials [13], guidelines for systematic reviews [14], guidelines on publishing micro-array data [15], prevention of digital manipulation of images [16], and other issues related to publishing biomedical data. Don't feel pressed by all this, it is meant to assist you in getting your manuscripts up to the currently advocated international quality standards.

\section{THE PEOPLE}

But how does all this come about? Well, it is down to the smooth interplay between the professional team of the European Respiratory Society (ERS) Publications Office in Sheffield (just have a look) [17], the Editors on the Board [18] and the many Reviewers who volunteer to check the quality of our papers [19]. This is a truly international - in fact, a global enterprise. We are pleased to say that the ERS has extended our mandate as Chief Editors for another 2 years, until January 2009. This means that the current Editorial Board will continue until that time.

We have also welcomed a few very distinguished new members onto the Editorial Board. Alan Leff from Chicago (IL, USA) has become our new Section Editor in the fields of cell biology, immunology, pathology, pharmacology and genetics. Peter Le Souëf has become Section Editor for the paediatric field, and switched positions with Jorrit Gerritsen, who is now an Associate Editor and Vice-President of the ERS. Urs Frey, Tobias Welte and Marius Hoeper have also become new Associate Editors, whilst Allan Hackshaw from London (UK) has agreed to be our new Statistical Editor. Jörgen Vestbo, Irfan Rahman and Christian Melot have had to retire from the board given their other heavy commitments. We would like to thank them very much for their enormous input into the quality of the ERJ. Special thanks also go to Susan Chinn, who retired from her position in London and thereby from the ERJ as well. Thank you, Sue, for the unflagging statistical guidance you gave to countless numbers of authors and to us as Editors!

But most of all we are indebted to Erik Berglund from Gothenburg (Sweden), who stepped down from the Editorial Board during the Munich Congress. Erik's editorial achievements can hardly be summarised. In 1974 he became the Chief Editor of the Scandinavian Journal of Respiratory Disease. Then, in 1980, he started the European Journal of Respiratory Disease, for which he was Chief Editor until 1987. In 1988 he was one of the founding fathers of the ERJ, together with Philip Quanjer, Paul Vermeire, Jean-Claude Yernault and Peter Howarth. He was Chief Editor until 1994, and ever since, Erik has contributed to the ERJ, particularly as experienced advisor for Cases for Diagnosis. But Erik has given much more than that. He has a hawk-eye for weaknesses and inconsistencies in data in papers that have been submitted... or already published. His contributions have been invaluable and we hope we continue to receive emails such as: "In the shade of an old apple tree I glanced through the August 2006 ERJ issue, and figure $x$ on page $y$ worries me because....". Thank you, Erik, for the past 32 years and mostly for injecting the ERJ with style!

All this illustrates a delightful balance between dynamics and innovation on the one hand, and consistency and experience on the other. This is the way we like it; this is our ERJ.

\section{REFERENCES}

1 West JB, Watson RR, Fu Z. The human lung: did evolution get it wrong? Eur Respir J 2007; 29: 11-17.

2 Macklem PT, Cardoso P, Snell G, et al. Airway bypass: a new treatment for emphysema. Proc Am Thor Soc 2006; 3: A726.

3 Herth FJF, Ernst A, Eberhardt R, Vilmann P, Dienemann H, Krasnik M. Endobronchial ultrasound-guided transbronchial needle aspiration of lymph nodes in the radiologically normal mediastinum. Eur Respir J 2006; 28: 910-914.

4 Rydell-Törmänen K, Uller L, Erjefält JS. Direct evidence of secondary necrosis of neutrophils during intense lung inflammation. Eur Respir J 2006; 28: 268-274.

5 Calverley P, Pauwels R, Löfdahl C-G, et al. Relationship between respiratory symptoms and medical treatment in exacerbations of COPD. Eur Respir J 2005; 26: 406-413.

6 Brown RH, Wizeman W, Danek C, Mitzner W. Effect of bronchial thermoplasty on airway distensibility. Eur Respir J 2005; 26: 277-282.

7 Welcome Europe. Monitoring, training, consultancy on European funding and public affairs. www.welcomeurope. com/default.asp?id=1110\&idpgm $=11728$.

8 International Committee of Medical Journal Editors. Uniform requirements for manuscripts submitted to biomedical journals: writing and editing for biomedical publication. www.icmje.org/.

9 Council of Science Editors. Ghostwriting, medical writers, and ethics-16. www.councilscienceeditors.org/services/ bboard1 $/$ thread.cfm?threadid $=152 \&$ messages $=1$.

10 von Elm E, Poglia G, Walder B, Tramèr MR. Different patterns of duplicate publication. An analysis of articles used in systematic reviews. JAMA 2004; 291: 974-980.

11 European Respiratory Society. ERS guidelines: conflict of interest. www.ersnet.org/ers/default.aspx?id_dossier $=$ 28172\&id_fiche $=162308 \& i d \_l a n g u e=3$.

12 ClinicalTrials.gov. About ClinicalTrials.gov. www. clinicaltrials.gov/ct/info/about.

13 Consort. E-checklist and flowchart. www.consortstatement.org/Downloads/download.htm.

14 Improving the quality of reports of meta-analyses of randomized controlled trials: the QUOROM statement checklist. www.consort-statement.org/QUOROM.pdf. 
15 MIAME Checklist. www.mged.org/Workgroups/MIAME/ miame_checklist.html.

16 The Scientist. How to guard against image fraud. www.the-scientist.com/2006/3/1/24/1/.

17 European Respiratory Society. Publications Office. www.ersnet.org/ers/default.aspx?id=203.
18 European Respiratory Society. European Respiratory Journal Editorial Board. http://erj.ersjournals.com/misc/ edboard.shtml.

19 European Respiratory Society. European Respiratory Journal List of Reviewers. http://erj.ersjournals.com/ misc/reviewers.shtml. 